9. ДКА. Стратегія космічної діяльності України на період до 2022 року. URL: https://www.nkau.gov.ua/ua/activity/stratehiia-do-2022-roku.

10. Федорчак О.В. Класифікація механізмів державного управління. Демократичне врядування: електронне наукове фахове видання. 2008. № 1. URL: http://www.nbuv.gov.ua/ejournals/DeVr/2008_01/ O_Fedorchak.pdf

11. Державне управління: Словник_довідник / За заг. ред. В.М. Князєва, В.Д. Бакуменка. К.: УАДУ, 2002. 228 с.

DOI https://doi.org/10.30525/978-9934-26-045-2-19

\title{
СФЕРИ ЗАСТОСУВАННЯ СУЧАСНИХ ЕЛЕКТРОННИХ ТЕХНОЛОГІЙ В ПУБЛІЧНОМУ УПРАВЛІННІ
}

\author{
Динник I. П. \\ кандидат наук з державного управління, \\ асистент кафедри публічного управління та адміністрування \\ Київського національного торговельно-економічного університету \\ м. Київ, Украӥна
}

Органи публічної влади використовують електронні технології (від автоматизації до використання штучного інтелекту) для поліпшення життя громадян. Нове покоління навчаючих комп'ютерні інновації вже перевершує людей за якістю інтелекту як стратегічного інструменту економічного розвитку країни і вдосконалення іiі публічного управління.

Наразі по всьому світу відбувається цифрова трансформація публічного управління. Автоматизація щоденної роботи публічних службовців - це одне 3 ключових рішень для економії коштів державного бюджету України. Урядові організації, усвідомлюючи переваги автоматизації, використовують такі новітні технології, як аналіз великих даних, штучний інтелект (ШІ), чат-боти. Подібні технології, сприяють збереженню праці, викликають у наукових колах і наснагу, і водночас занепокоєння.

Впроваджуючи платформу великих даних, держави можуть отримати доступ до величезних обсягів актуальної інформації, важливої для публічного управління. Позитивний ефект, який можуть надати великі дані, майже нескінченний. Це дозволить уряду не тільки 
точно визначати області, які потребують уваги, а й надавати цю інформацію в режимі реального часу [1].

Системи штучного інтелекту були успішно впроваджені в різні споживчі програми і призначені для користувача апаратні платформи, такі як Alexa, Siri, Google Home i iн. Однак їх впровадження в робочі процеси на державному рівні відбувається досить повільно.

Використання ШІ в процесі надання державних послуг - це питання часу. Державі необхідно брати приклад 3 комерційних компаній, які вже намагаються впроваджувати Ш в роботу кол-центрів або, наприклад, для аналізу поведінки споживачів.

Важливо зазначити, що Україна вже зробила крок в цьому напрямі, оскільки 02 грудня 2020 року Кабінет Міністрів України схвалив проєкт розпорядження «Про схвалення Концепції штучного інтелекту в Україні», яким передбачено схвалення відповідної Концепції на період до 2030 року, визначено пріоритетні сфери та основні завдання розвитку технологій штучного інтелекту в Україні. Для досягнення мети Концепції у сфері публічного управління слід забезпечити виконання таких завдань :

- формування переліку адміністративних послуг, рішення за якими приймаються автоматично, за мінімальної участі державних службовців;

- дослідження та застосування технологій штучного інтелекту у сфері охорони здоров'я, зокрема щодо протидії епідеміям та пандеміям, а також прогнозування та попередження епідемічних спалахів у майбутньому;

- розвиток технологій штучного інтелекту для цифрової ідентифікації та верифікації осіб, у тому числі для надання державних послуг;

- застосування технології штучного інтелекту для проведення аналізу, прогнозування та моделювання розвитку показників ефективності системи публічного управління і т.д.

В даний час співробітники державного апарату вже не в змозі ефективно використовувати наявний обсяг даних без допомоги технічних засобів. Технології штучного інтелекту дозволять зробити економіку цифровою.

Говорячи про застосування інтелектуальних технологій в публічному управлінні, варто згадати ідею створення розумних міст (smartcity). Головна мета програми розумного міста - підвищення ефективності роботи всіх муніципальних служб. Розумне місто повинно 
працювати на основі штучного інтелекту та взаємодіяти 3 цифровою міською інфраструктурою, яка буде безперешкодно з'єднуватися, а також спілкуватися зі смартфонами і відповідними пристроями громадян. Все це допоможе програмному забезпеченню, яке вже знає, як адаптувати міські служби, реагувати на проблеми і забезпечувати безперебійну роботу [3].

Використання великої кількості технологій може допомогти сучасному місту стати більш ефективним і поліпшити життя його громадян, і це вже відбувається в багатьох країнах. Міста по всьому світу будують основи інфраструктури для розумного міста. Деякі надають безкоштовний Wi-Fi в громадських місцях, інші створюють розумну систему для управління світлофорами, а треті формують основу для майбутніх проєктів [2].

Таким чином, роль новітніх технологій в публічному управлінні ще необхідно вивчати більш досконало та глобально. Скоріше за все, що саме 2021 рік стане роком використання більш розумних технологій в публічному управлінні.

\section{Література:}

1. Алексеева Л. Н. Сферы применения новейших электронных технологий в государственном управлении // Вестник РЭА им. Г.В. Плеханова. 2019. № 2 (104). URL: https://cyberleninka.ru/ article/n/sfery-primeneniya-noveyshih-elektronnyh-tehnologiy-vgosudarstvennom-upravlenii (дата обращения: 21.02.2021).

2. Smart Infrastructure Can Make Buses More Reliable. URL: http://www.governmentbusiness.co.uk/news/02112018/smart-infrastructure-can-make-busesmore-reliable (accessed : 21.02.2021).

3. The Fast-Follower Strategy for Technology in Government. URL: http://www.governing.com/blogs/bfc/col-fast-follower-strategytechnology-government.html (accessed : 21.02.2021). 